\title{
Effects of high frequency chest compression on respiratory system mechanics in normal subjects and cystic fibrosis patients
}

\author{
RICHARD L JONES PhD, RICHARD T LESTER BSc, NEIL E BROWN MD \\ University of Alberta, Edmonton, Alberta
}

RL JONES, RT LeSter, NE Brown. Effects of high frequency chest compression on respiratory system mechanics in normal subjects and cystic fibrosis patients. Can Respir J 1995;2(1):40-46.

Orjective: To investigate the short term effects of high frequency chest compression (HFCC) on several indices of respiratory system mechanics in normal subjects and piltients with cystic fibrosis (CF).

DESIGN: Comparative physiological approach. Subjects were blinded to 10 randomized $\mathrm{HFCC}$ settings $(5,10,15,20$ and $25 \mathrm{~Hz}$ ) with eateh applied at the lowest and at the highest background vest pressure.

SetTing: Pulmonary function and Iung mechimics laborattory, University of Alberta.

PARTICIPANTS: Ten normal male volunteers $(24.2 \pm 3.8$ years) and II clinically stable CF patients $(23.4 \pm 0.7$ years $)$. Normal subjects were nonsmokers who had normal lung function. The $\mathrm{CF}$ patients had a wide range of atirwaly obstruction.

INTERVENTIONS: HFCC wals supplicd by oscillating a pneumatic vest that covered the entire lorso. Balloon tipped catheters were used to measure esophageal (Pes) and external chest wall (Pew) pressures. Changes in end-expiratory lung volume (EELV) during HFCC were measured from a spirogram and were compared with bascline functional tesidual capacity (FRC). The HFCC induced air movement at the mouth, oscillated tidal volume (Vose), wals measured by reverse plethysmography.

RESULTS: Both normals and CF palients had similar changes in Pes and EELV. At the highest background vest pressure and at the higher oscillation frequencies, EELV decreased approximately $30 \%$ from the no-HFCC baseline FRC. Vose decreased with increasing oscillation trequency but normals had higher Vosc than CF patients at each frequency. Conversion of Vosc to flow ( Vosc) revealed that the highest Vosc occurred between 10 and $15 \mathrm{~Hz}$ for both normals and CF patients. Also, Vosc was dependent on the overall airway function. Low forced expired volume in $1 \mathrm{~s}$ resulted in low Vose, especially when Vose was measured during spontaneous expiration.

CONCLUSIONS: CF patients with moderate or severe airwaly obstruction may gain maximal benefit from HFCC therapy when low vest pressure is used at an oscillation frequency of 10 to $15 \mathrm{~Hz}$. The low vest pressure minimizes the decrease in EELV and 10 to $15 \mathrm{~Hz}$ maximics Vosc. (l'our résumé, vir page 4 )

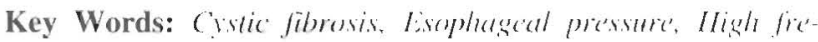
tuency chest compression, Lang functiont 


\section{Effets d'une compression thoracique à haute fréquence sur la mécanique du système respiratoire chez des sujets sains et chez des patients atteints de fibrose kystique}

OBJectra : Étudier les eflets a comlt lerme d'unc compression thoracique à haute fréquence sur plusieurs indices de la mécanique du système respiratoire chez des sujets sains et chez des patients atteints de fibrose kystique (FK).

MODÈLE : Approche physiologique comparative. Étude en aveugle sur des sujets soumis à 10 niveaux de compression thoracique à haute fréquence randomisés $(5,10,15,20,25 \mathrm{~Hz})$, chacun appliqué à la pression de référence la plus basse et la plus haute d'un gilet.

Contexte : Laboratoire dexplorations fonctionnelles el do mécanique pulmonaire de l'Université d'Alberta.

PARTICIPANTs : Dix hommes volontaires sains (24.2 $\pm 3,8$ ans) et 11 patients atteints de fibrose kystique cliniquement stable (23,4 46,7 ans). Les volontaires sains étaient des non-fumeurs et démontraient une fonction pulmonaire normale. Les patients atteints de FK présentaient une obstruction bronchique de degré variable.

INTERVENTIONS : La compression thoracique à haute fréquence a été appliquée en oscillant un gilet pneumatique recouvrant le thorax. Des cathéters à extrémité gonflable ont été utilisés pour mesurer la pression oesophagienne et les pressions à l'extéricur de la paroi thoracique. Les changements dans le volume pulmonaire en fin d'expiration pendant la compression thoracique à haute fréquence ont été mesurés d'après un spirogramme et comparés avec lat capacité résiduelle fonctionnelle (CRL) de basce. Le mouvement d'air à la bouche induil par la compression thoracique à haute fréquence, volume courant ohtenu par oscillation. était mesuré par pléthysmographic inverséc.

RÉSUltats : Les patients sains el céx alteints de FK présentaient des changements similaires dans la pression oesophagienne el dans le volume pulmonaire en fin d'expiration. À la pression de référence la plus haute du gilet et aux fréquences d'oscillations les plus hautes, le volume pulmonaire en fin d'expiration chutait approximativement de 30 \% prer rapport at la CRF de base non soumise a la compression thoracique de haute fréquence. Le volume courant obtenu par oscillation chutait bors d"une atumentation de la fréquence des oscillations, cependant. a chaque fréquence, les sujets sains présentaient un volume courant oblenu par oscillation plus élevé que celui des patlents atteints de FK. Lit conversion du volume courant obtenu par oscillation en débit a révélé quion obteniait le débit le plus élevé entre 10 el 15 If à lat fois pour les sujets sains et ceux atteints de FK. De méme le débit obtenu par oscillation était dépendant de la fonction respiratoire dans son ensemble. Un volume expiratoire maximum/seconde faible résultait en un débit obtenu par oscillation faible, en particulier quand le débit obtenu par oscillation était mesuré aut cours d'une expiration spontanée.

Conclusions : Les patients atteints de FK et présentant um obstruction modérée ou grave des voies aériennes pourratient largement bénéficier d'une thérapie par compression thoracique à haute fréquence lorsque une faible pression est appliquée à l'aide d'un gilet à une fréquence d'oscillations de 10 à $15 \mathrm{~Hz}$. La faible pression du gilet minimise la chute du volume pulmonaire en fin d'expiration tandis que 10 à $15 \mathrm{~Hz}$ maximalisent le débit obtenu par oscillation.
$\mathrm{H}$ IGH FREQUENCY (IIEST COMPRESSION (HFCC) RI:PORT edly increases nucus clearance in normat animals ( $1-3$ ) and in pattents with lung disease (4-6). In patients. HFCC can be delivered by a pneumatic vest that strrounds the thorax. The vest is inflated 10 at positive background pressure over which pressure oscillations of 5 to $25 \mathrm{~Hz}$ are superimposed. The patient can either breathe spontaneously during continuous HFCC or HFCC can be aclivated during expiratory breathing manocuvres. Enhanced mucociliary clearance has been attributed. at least in part, to high oscillated air flow in the airways $(1-3)$.

The concept of HFCC was linst described in 1966 by Beck (4). He described the use of a belt-like bladder that surrounded the upper abdomen and lower thorax which was

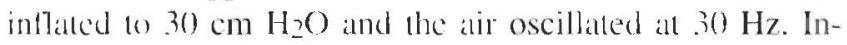
creases in mucus expectoration, vilal capacity and maximal voluntary ventibation were reported for a patient with chronic obstruclive pulmonary disease. Then in the mid-1980. King el al (1.2) reported that HFCC enhanced tracheat and periphcral mucociliary clearance in normal dogs. The cull and pump system used by King et at produced peat oscillatory cuff pressures of up to $100 \mathrm{~cm} \mathrm{H}_{2} \mathrm{O}$, and $13 \mathrm{H} /$ was found is be the most effective mucus clearance frequency. Since then, HFCC studies on cystic fibrosis (CF) patients have demonstrated increased short term sputum production (5-6) and improved peripheral ventilation (6). Furthermore, Warwick and Hansen (6) reported improved lung function in 15 ol i6 CF patients after 22 months of daily HFCC use.
In view of its reported elfectiveness and the availability of a commercially available device, the clinical use of HFCC is likely 10 increase. However, studies investigating the short term effects of HFCC on respiratory system mechanics in human subjects have not been reported.

We studied nomal subjects and CF patients to detormino the effects of HFCC on external chest wall pressure (Pcw), pleural pressure, end-expiratory lung volume (EELV), oscillated tidal volume (Vose) and oscillated ail flow (Vosc). Some important differences were found between normal subjects and CF patients.

\section{PATIENTS AND METHODS}

Subjects: This study was approved by the locull ethics committee and signed informed consent was obtained from all subjects. Ten normal subjects and 11 CF patients were studied. The normal subjects comprised nonsmoking volunteers $24.2 \pm 3.8$ ycars old with normal lung function. The CF palients averaged $23.4 \pm 6.7$ years, with forced expiraltory volume in $1 \mathrm{~s}\left(\mathrm{FEV}_{1}\right)$ ranging from 21 to $111 \%$ of predicted values (7). All of the CF patients were in a clinically stable phase of their disease and daily routine and medical treatlments were unaltered for this study.

Lung function: Pulmonary function tests were done within $1 \mathrm{~h}$ before the HFCC study. Baseline lung function, which included spirometry and lung volumes, was determined in all subjects. For the CF patients, lung volumes were measured with both the helium dilution and body plethysmograph 
TABLE 1

Anthropometric and baseline lung function for all subjects*

\begin{tabular}{|c|c|c|}
\hline & Normals & $\begin{array}{l}\text { Cystic fibrosis } \\
\text { patients }\end{array}$ \\
\hline Age (years) & $24.2 \pm 3.8$ & $23.4 \pm 6.7$ \\
\hline Height $(\mathrm{cm})$ & $177.3 \pm 4.8$ & $175.0 \pm 7.1$ \\
\hline Weight $(\mathrm{kg})$ & $78.2 \pm 8.7$ & $63.9 \pm 6.8$ \\
\hline $\begin{array}{l}\mathrm{FEV}_{1}(\% \text { predicted }) \\
\text { (range) }\end{array}$ & $\begin{array}{c}100.8 \pm 10.7 \\
(85-123)\end{array}$ & $\begin{array}{l}63.7 \pm 26.9 \\
(21-111)\end{array}$ \\
\hline $\mathrm{FEV}_{1} /$ FVC $(\%)$ & $82.3 \pm 5.8$ & $55.2 \pm 16.3$ \\
\hline $\mathrm{FRCHe}(\%$ predicted $)$ & $118.4 \pm 12.3$ & $123.9 \pm 14.5$ \\
\hline RVHe (\% predicted) & $89.0 \pm 18.1$ & $122.4 \pm 51.5$ \\
\hline TLC $\mathrm{HO}_{\mathrm{H}}$ (\% predicted) & $101.0 \pm 7.4$ & $104.0 \div 17.3$ \\
\hline TLC & - & $119.8 \pm 43.6$ \\
\hline
\end{tabular}

*All subjects were male. Data presented as mean $\div$ SD. FEV Forced expiratory volume in $1 \mathrm{~s}$; FRC Functional residual capacity; FVC Forced vital capacity; He Helium dilution; PI Body plethysmography; TLC Total lung capacity. Predicted values are from references 7 and 8

methods, but only helium dilution values were obtained for the normals. A Gould 2400 PFT system and a Gould 2800) Autobox were used (Gould, Ohio). Baseline helium dilution functional residual capacity (FRC) measurements were taken in triplicate with at least 5 mins between measurements. The average of these three values was used to determine the EELV during HFCC. Anthropometric and baseline lung function data for the two study groups are presented in Table I with normal values for spirometry and lung volumes obtained from Morris et al (7) and Crapo et al (8), respectively. HFCC system: The ThAIRapy system (American Biosystems, Minnesota) was used for HFCC. The system contains an air-pulse generator consisting of a high volume regenerative blower that provides a constant background pressure and a rotary valve that produces alternating positive and zerogauge pressures. These pressures are applied to a pneumatic vest via two flexible hoses. The deflated vest covers the entire thorax and extends to the iliac crest. In this study, the vest was fitted to each subject by having the subject inhale to total lung capacity and then securcly fastening the vest in place. This allowed for subjects to take deep breaths withoul being osstricted by the noncompliant vest.

The vest's background pressure can be regulated and the frepuency of the pulse pressures is controllable between 5 and $25 \mathrm{~Hz}$. Ten of a wide range of possible pressure and frequency combinations were investigated: 5, 10, 15, 20 and $25 \mathrm{~Hz}$ oscillation frequencies and the lowest (LP) and highest (HP) background pressure settings. Activation of the HFCC system is controlled by a 'dead man's' switch designed for control by the patient, but in this study it was controlled by the investigator.

Lung mechanics measurements during HFCC: To study the short 1crm clfects of HFCC, a system capable of simultaneously measuring several indices of respiratory system mechanics was devised (Figure 1). These included Pcw, esophageal pressure (Pes), changes in EELV, spontaneous lidal volume $\left(V_{T}\right)$, spontancous breathing frequency $(1)$ and

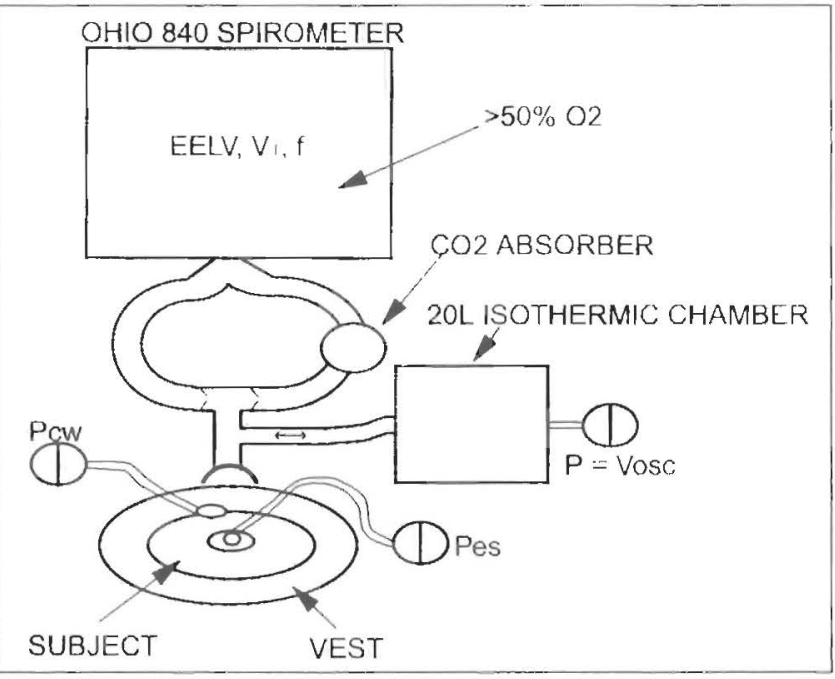

Figure 1) Diagram of the system used to measure simultaneously external chest wall pressure (Pcw), esophageal pressure (Pes). oscillated tidal volume (Vosc), end-expiratory lung volume (EEI.V). tidal wolume $\left(V_{T}\right)$ and frequency $(f)$. The ThAIRapy air pulse gene'. ator is not shown but connects to the rest viat we flexible hoses

the HFCC induced volume change at the mouth, Vosc. Both pulse pressure (amplitude of the pressure wave) and mean pressure (pressure at midpulse) were obtained for PcW and Pes (Pcw-pp, Pes-pp, Pcw-m, and Pes-m, respectively). All measurements were recorded on a four-channel Gould strip chart recorder and values for Pcw, Pes and EELV werc obtained at the end of a spontaneous expiration. Two meas. urements of Vosc were made during HFCC for each of the I0 frequency-pressure combinations: one Vosc was measured at the middle of a spontaneous inspiration and the other was measured at the middle of expiration for the same spontaneous breath to ensure a constant lung volume for the two measurements.

Pcw was measured via a $120 \mathrm{~cm}$ long and $0.20 \mathrm{~cm}$ inner diameter catheter with a latex balloon covering its tip. The balloon was $4 \mathrm{~cm}$ long and $2 \mathrm{~cm}$ in diameter and partially inflated with $1.5 \mathrm{~mL}$ of air. The catheter was taped to the external chest wall so that the balloon was 2 to $4 \mathrm{~cm}$ below the left pectoral muscle and under the vest. A Validyne MP $45\left( \pm 50 \mathrm{~cm} \mathrm{H}_{2} \mathrm{O}\right.$ ) (Validyne Engineering Corp, California) pressure transducer was used and the frequency responsc of the chest wall balloon system was flat through $25 \mathrm{~Hz}$.

Pes was measured using the method described by Milic Emili et al (9). An esophageal balloon was connected to a Validyne MP $45\left( \pm 50 \mathrm{~cm} \mathrm{H_{2 }} \mathrm{O}\right.$ ) transducer via a 9() $\mathrm{cm}$ long and $0.15 \mathrm{~cm}$ inner diameter catheter. This was then connected to a $60 \mathrm{~cm}$ long $0.50 \mathrm{~cm}$ inner diameter catheter. The response of the Pes measurement system was frequency dependent and correction factors were used to account for this. The correction factors ranged from 1.00 ) 101.15 at $5 \mathrm{H} /$ and $25 \mathrm{~Hz}$, respectively.

The immediate HFCC induced changes in EELV, $V_{\mathrm{T}}$ and f were measured by a rebreathing system (Figure I) with scparate inspiration and exhalation pathways (Ohio 840, 
TABLE 2

Short term ventilation response to HFCC

\begin{tabular}{|c|c|c|c|c|c|c|}
\hline & $\mathbf{V}_{\mathrm{T}, \mathrm{b}}(\mathrm{L})$ & $\mathrm{V}_{\mathrm{T}, \mathrm{HFCC}}(\mathrm{L})$ & $f_{b}($ beats $/ \mathrm{min})$ & $f_{\text {HFCC }}$ (beats/min) & $\dot{V}_{E, b}(L / m i n)$ & $\dot{V}_{E, H F C C}(L / m i n)$ \\
\hline Normal subjects & $0.59 \div 0.04$ & $0.66 \pm 0.11$ & $15.3+0.7$ & $16.4 \pm 1.3$ & $8.2+0.5$ & $10.0 \div 1.8$ \\
\hline Cystic fibrosis patients & $0.95 \pm 0.06$ & $1.08 \pm 0.06$ & $11.3 \pm 0.4$ & $11.9 \div 0.7$ & $10.1+0.7$ & $12.2 \pm 1.0$ \\
\hline
\end{tabular}

Data presented as mean $\pm S D ; n=100$ for both groups. b Baseline (no HFCC); f Frequency: HFCC High frequency chest compression; $V_{E}$ Total ventilation; VT Tidal volume

TABLE 3

Mean values for the various measurements during HFCC

\begin{tabular}{|c|c|c|c|c|c|c|c|c|c|c|c|c|c|c|}
\hline & \multicolumn{2}{|c|}{ Pcw-m $\left(\mathrm{cmH}_{2} \mathrm{O}\right)$} & \multicolumn{2}{|c|}{ Pcw-pp $\left(\mathrm{cmH}_{2} \mathrm{O}\right)$} & \multicolumn{2}{|c|}{ Pes-m $\left(\mathrm{cmH}_{2} \mathrm{O}\right)$} & \multicolumn{2}{|c|}{ Pes-pp $\left(\mathrm{cmH}_{2} \mathrm{O}\right)$} & \multicolumn{2}{|c|}{ EELV (\%FRC) } & \multicolumn{2}{|c|}{$\operatorname{Voscl}(\mathrm{mL})$} & \multicolumn{2}{|c|}{$\operatorname{Vosc}_{\mathrm{E}}(\mathrm{mL})$} \\
\hline & LP & HP & LP & HP & LP & HP & LP & HP & LP & HP & LP & HP & LP & HP \\
\hline Normals & $n=10$ & $n=10$ & $n=10$ & $n=10$ & $n=10$ & $n=10$ & $n=10$ & $n=10$ & $n=10$ & $n=10$ & $n=10$ & $n=10$ & $n=10$ & $n=10$ \\
\hline $5 \mathrm{~Hz}$ & 14.0 & 28.3 & 11.0 & 19.2 & -2.6 & -1.6 & 4.9 & 7.5 & 91.4 & 82.6 & 53.8 & 78.0 & 38.8 & 61.9 \\
\hline $10 \mathrm{~Hz}$ & 14.2 & 31.2 & 6.3 & 10.9 & -2.7 & -0.4 & 3.7 & 6.5 & 91.1 & 83.4 & 33.6 & 42.3 & 29.0 & 42.5 \\
\hline $15 \mathrm{~Hz}$ & 16.7 & 38.7 & 8.4 & 12.7 & -2.6 & 0.5 & 4.2 & 6.9 & 91.3 & 79.9 & 23.5 & 26.8 & 19.5 & 22.9 \\
\hline CF & $\mathrm{n}=11$ & $n=11$ & $n=11$ & $n=11$ & $n=7$ & $n=7$ & $n=7$ & $n=7$ & $n=11$ & $n=11$ & $n=11$ & $n=11$ & $n=11$ & $n=11$ \\
\hline B & 0 & 0 & 0 & 0 & -2.7 & -2.7 & 0 & 0 & 100 & 100 & 0 & 0 & 0 & 0 \\
\hline $5 \mathrm{~Hz}$ & 13.0 & 31.5 & 12.4 & 21.6 & 0.4 & 2.5 & 5.8 & 9.4 & 91.3 & 84.5 & 42.9 & 62.2 & 30.9 & 30.1 \\
\hline $10 \mathrm{~Hz}$ & 16.6 & 37.2 & 8.2 & 14.0 & 0.6 & 4.0 & 4.6 & 7.5 & 91.1 & 80.5 & 24.3 & 33.7 & 14.3 & 174 \\
\hline $15 \mathrm{~Hz}$ & 20.4 & 41.5 & 8.9 & 14.3 & 0.5 & 4.3 & 4.6 & 7.4 & 88.8 & 79.9 & 17.0 & 22.6 & 10.6 & 9.5 \\
\hline
\end{tabular}

B Baseline; BTPS Body temperature, ambient pressure and saturated with water vapour; CF Cystic fibrosis; EELV End-expiratory lung volume; FRC Functional residual capacity: HFCC High frequency chest compression; HP Highest HFCC background pressure; LP Lowest HFCC background pressure; PCw-m Mean chest wall pressure; Pes-m Mean esophageal pressure; Pcw-pp Chest wall pulse pressure; Pes-pp Esophageal pulse pressure: Voscl Oscillated tidal volume (BTPS) during spontaneous inspiration: VosCE Oscillated tidal volume (BTPS) during spontaneous expiration

(Ohio Medical Products, Wisconsin). Carbon dioxide was removed and the intial fraction of inspired oxygen $\left(\mathrm{F}_{1} \mathrm{O}_{2}\right)$ wals sel at approximately 0.5 to allow several minutes of rebreathing. Each of the 10 combinations of bactiground pressure and oscillation frequency required 3 mins of rebreathing with the $\mathrm{F}_{1} \mathrm{O}_{2}$ restored between each combination. Oxygen saturation (Ohmeda Biox 3700). Ohmeda, Colorado) was monitored as a safety measure in the CF patients but oxygen saluration remalined between 97 and $100 \%$ in all patients.

The subjects breathed for 1 min from the closed circuit without superimposed HFCC to obtain the baseline spirogram. Then, when HFCC was started, the increased external chest wall pressure caused a shift in the spirogram to a new and stable position which was measured as EELV. HFCC continued for 2 mins. EELV during HFCC (expressed as \%FRC) was oblatined by use of the baseline helium dilution FRC and the HFCC induced change in EELV.

The exhalation pathway acted as a low pass filter so that rapid volume changes at the mouth caused by HFCC (Vosc) could be recorded as pressure changes in a $20 \mathrm{~L}$ isothermic chamber located near the mouth (Figure 1). The Vosc measurement was frequency dependent and correction lactors were used to obtain the true Vose. These correction factors ranged from $1.0(0) 101.55$ at $5 \mathrm{~Hz}$ and $25 \mathrm{~Hz}$, respectively. The correction lactors were obtained by oscillating the isothermic chamber with a Matrix oscillator connected either at the mouth picee or direclly to the chamber with a short piece of wide bore tubing. Airflow through the breathing system. cither inspiration or expiration. had no effect on Vosc measurement.

Since Vose approximated al sinusoidal wave, the mean Vosc during HFCC was calculated by multiplying the Vose by half the oscillation frequency al which it was measured.

Correlation coefficients were calculated and analysis of variance (ANOVA) tests were done to lest for differences between groups and within groups. Post-hoc comparisons were then done using the least signilicant difference test. Significant dillerences were taken at the $P<0.05$ level.

\section{RESULTS}

Esophageal pressure was obtained for all of the normal subjects but for only seven of the $11 \mathrm{CH}$ patients. Four patients were unable to tolerate the esophageal balloon. In this study, at wide range of pressures was delivered to the chest wall due to the different background pressure settings (LP and HP) and the five different oscillation freytencies used. 


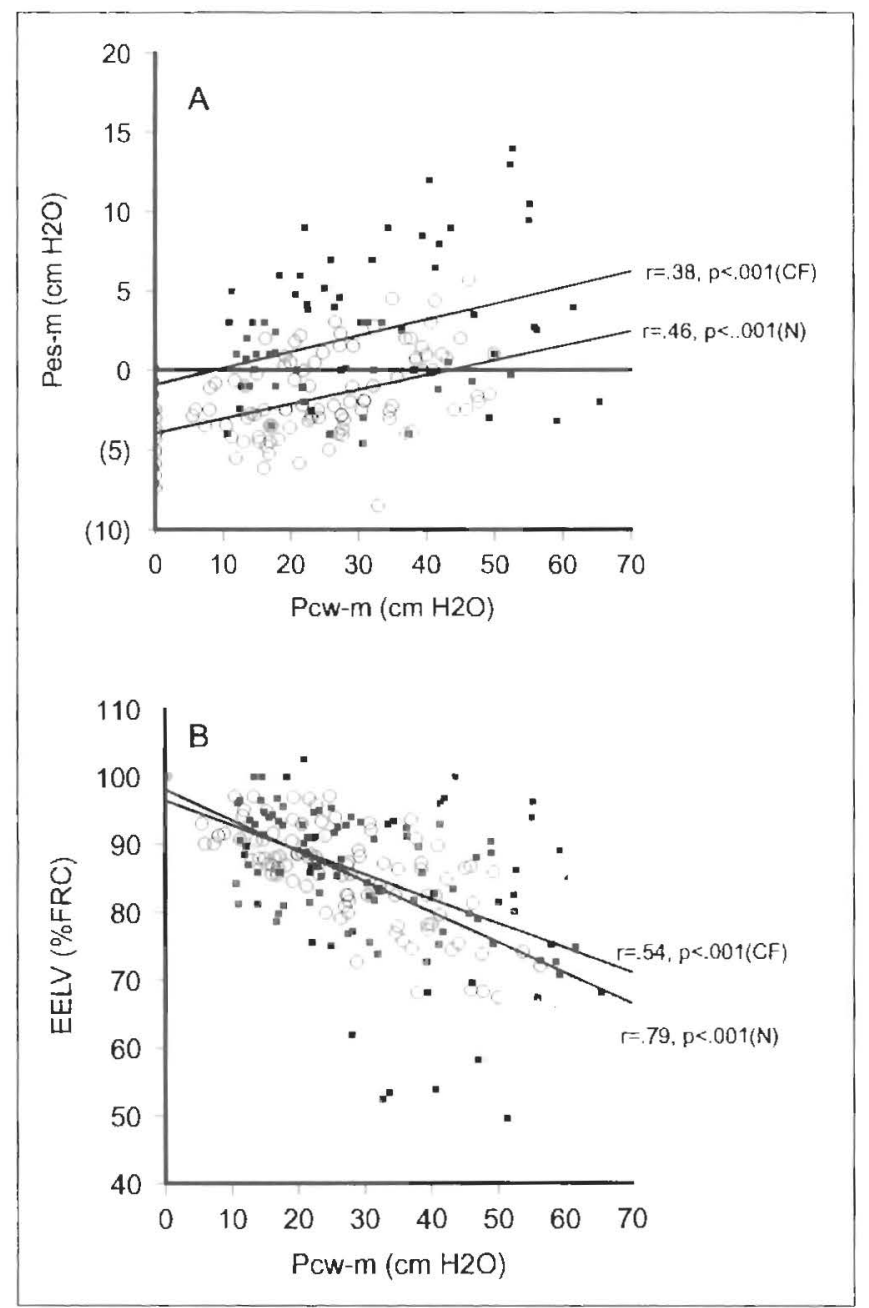

Figure 2) Effects of mean chest wall pressure $\left(P_{(21}-m\right) \mathbf{A}$ m mean esophageal pressure (Pes-m), and $\mathbf{B}$ on end-expiratory lung welume (EELV). O Normals $(N) ; \square$ Cistic fimosis (CF) paticuls; FRC Funcrional residual capacily

The effect of $\mathrm{HFCC}$ on $\mathrm{V}_{\mathrm{T}}$, f and total ventilation $\left(\dot{V}_{\mathrm{E}}\right)$ arc shown in Table 2. The CF patients breathed with signilicantly larger $V_{T}$, lower frequencies and larger ventilation rates than the normal subjects, and HFCC carused significant increases in all of these variables in both normals and CF patients. The HFCC data represent the mean for all I0 pressure-frequency combinations but the changes in breathing paltern were similar for all of the combinations.

Table 3 shows the mean values for the other mealsurements made before and during HFCC. For all subjects, the LP setting resulted in Pcw-m being approximately half the value obtained during HP. Compared with LP at the same oscillation frequency, HP always resulted in higher values for Pcwpp and Pes-pp, more positive Pes-m and lower EELV. In the normal subjects, Vose was alwalys higher during HP, regardless of whether Vose was measured during spontaneous inspiration or expiration. For the CF patients, Vose was also higher during HP when it was measured during spontaneous inspiration, but the differences in Vosc between LP and HP were insignificant when it was measured during spontaneous

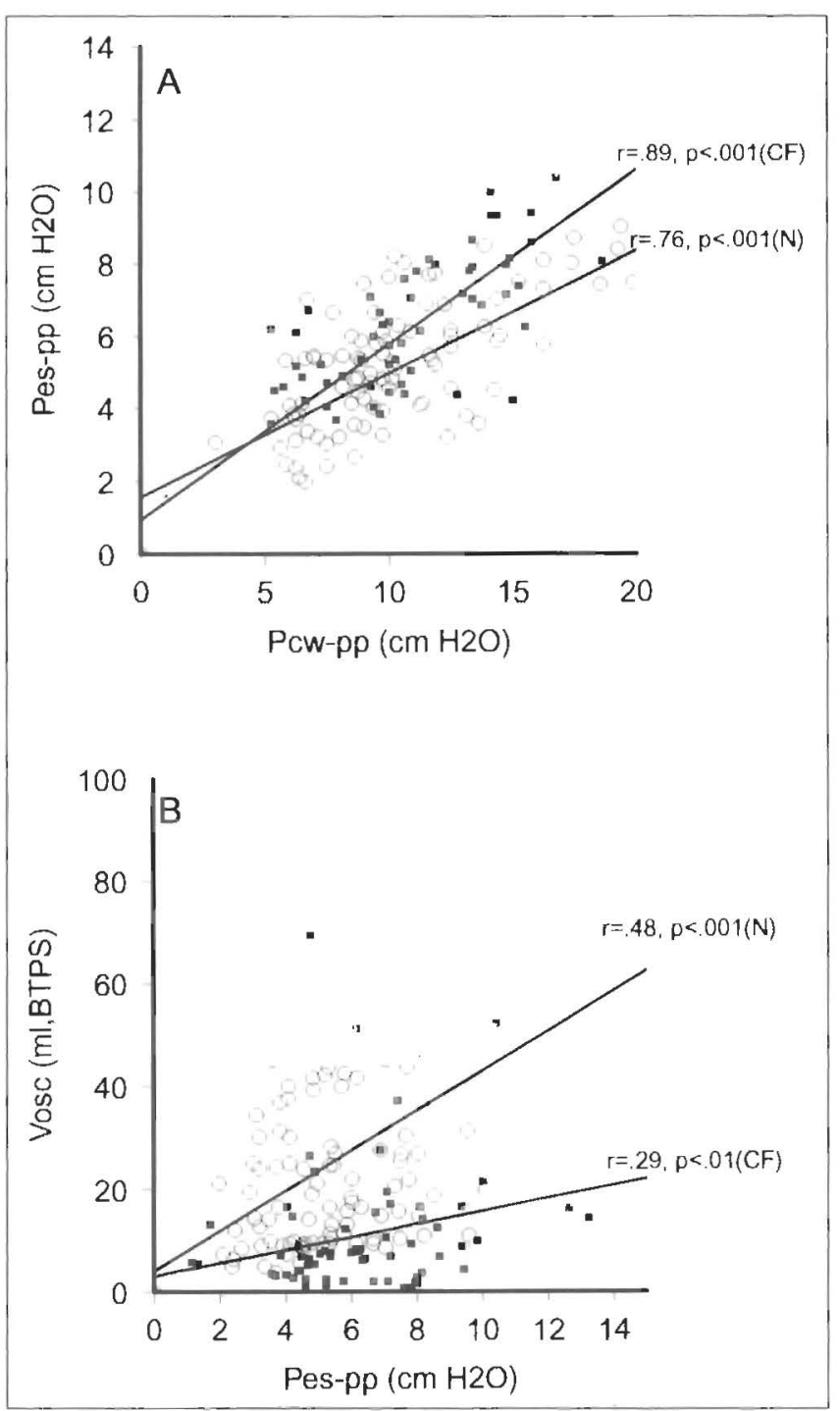

Figure 3) A Effects of chest wall pulse pressure $(P(w-p p)$ on esophageal pulse pressure (Pes-pp). B The effects of Pes-pp on oscillated tidal volume (Vosc). $\bigcirc$ Normals (N): $\square$ Cystic fibrosis (CF) patient:; BTPS Body temperature, ambient pressure and saturated with water verpour

expiration. For both normals and CF patients, Vosc dscreased exponentially as frequency increased.

The transmission of pressure from outside the chest to the pleural space is shown in Figure 2A. At FRC, withou HFCC, Pes-m averaged $-4.8 \mathrm{~cm} \mathrm{H}_{2} \mathrm{O}$ in the normal subjects and -2.7 $\mathrm{cm} \mathrm{H}_{2} \mathrm{O}$ in the CF patients. During HFCC, the changes in Pes-m were similar for the normals and CF patients, averaging $0.092 \mathrm{~cm} \mathrm{H} \mathrm{H}_{2} \mathrm{O} / \mathrm{cm} \mathrm{H}_{2} \mathrm{O}$ and $0.103 \mathrm{~cm} \mathrm{H}_{2} \mathrm{O} / \mathrm{cm} \mathrm{H}_{2} \mathrm{O}$, respectively.

As expected, increasing Pcw-m decreased EELV (Figure 2B). EELV decreased similarly for both normal subjects and CF patients. The lowest EELV seen in the normal group was $66 \%$ of the pre-HFCC FRC and in the CF group it was $50 \%$. In both instances the lowest EELV occurred at the HP $25 \mathrm{~Hz}$ setting. The lowest six values for EELV, seen in Figure 2B, came from the same CF patient.

The ability to transmit HFCC pulse pressures through the 


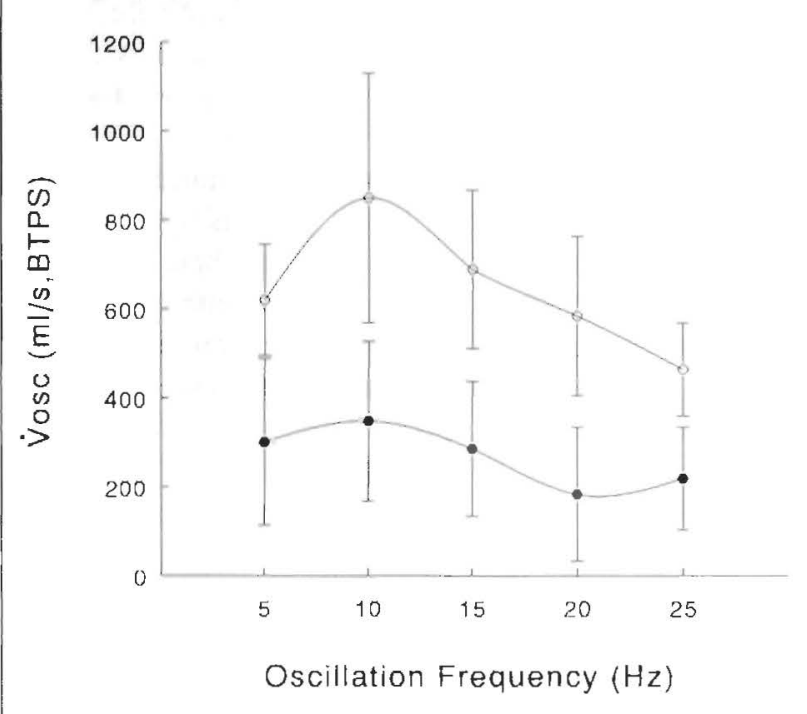

Figure 4) Effects of oscillation frequency on oscillated tidal flow (Vosc) during spontaneous expiration using the highest background pressure. Normals (N); Cystic fibrosis (CF); BTPS Body temperature, ambient pressure and saturated with water vapour. The two groups were significantly different at all frequenciss $(P<0.005)$

chest wall to the pleural space is indicated in Figure $3 \mathrm{~A}$. Increasing Pcw-pp was associated with higher Pes-pp in both the normal and CF groups. On average for the 10 experimental HFCC settings, Pes-pp was $50 \pm 6 \%$ of Pew-pp in normals and $50 \pm 5 \%$ of $\mathrm{Pcw}$-pp in CF patients. Each of the regressions in Figure $3 \mathrm{~A}$ was significant $(\mathrm{P}<0.001)$ but they were not significantly different from each other.

The effects of Pes-pp on Vose are shown in Figure 3B. Although there was a large scalter of points for both the normal subjects and CF patients the linear regressions were significant $(r=0.48$ and $\mathrm{r}=0.29$, respectively). For a given Pes-pp the Vosc, mealstred during spontaneous expiration, was approximately three times greater in normals than in $\mathrm{CF}$ pallients.

The effects of oscillation frequency on oscillated tidal flow rate in normals and CF patients during spontancous expiration are shown in Figure 4. Although the normals had much higher Vose than the CF patients, the highest Vosc occurred at $10 \mathrm{H} /$ in both groups. A similar pattern was scen for V́osc measured during spontaneous inspiration except that Vose peaked at $15 \mathrm{~Hz}$ and that Vose, like Vose, was higher during spontancous inspiration than during expiration. especially for the CF patients.

Figure 5 shows the effect of airway obstruction, as assessed by FEV 1 , on Vosc at $\mathrm{HP}$ and $15 \mathrm{~Hz}$. Regardless of whether Vosc was measured during spontaneous inspiration or spontaneous expiration, decreasing FEV 1 decreased Vosc. This effect was larger during spontaneous expiration even though the measurements were made at the same lung volume as during spontaneous inspiration. A similar effect of FEV 1 on Vose wals observed for all of the other HFCC

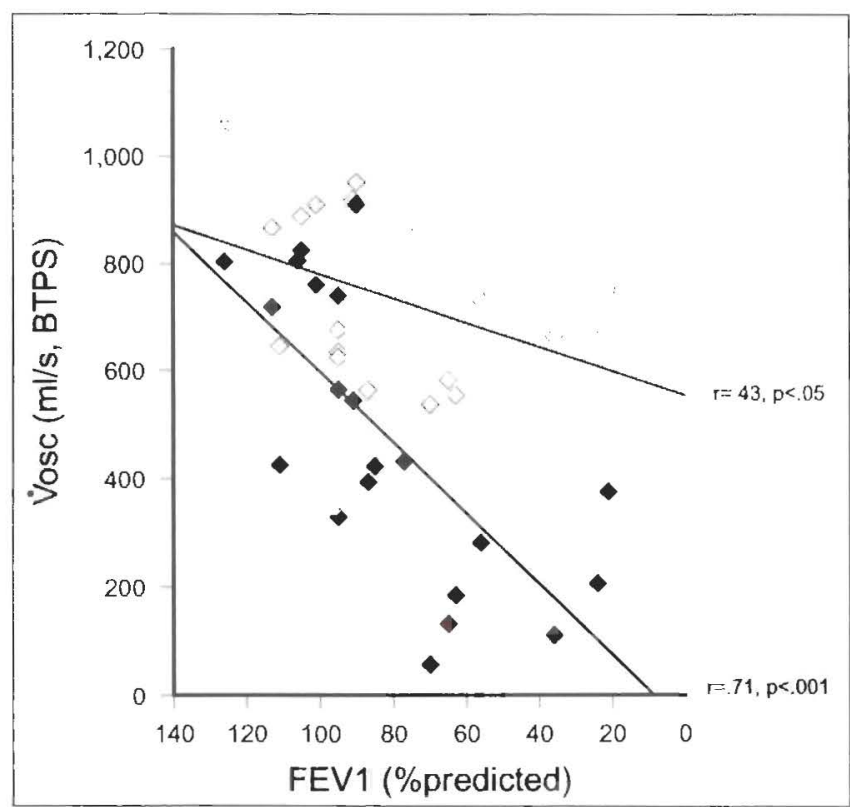

Figure 5) Effect of airway obstruction, depicted by forced expiratory volume in I $\mathrm{s}(\mathrm{FEV}$ ) on oscillated lidal flom ( Vose) al the hight pressure $15 \mathrm{~Hz}$ setting measured a midexpiration $(\downarrow)$ and mid-in-

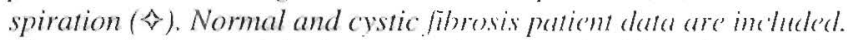
The results obtained during expiration we'es signific anth $(P<0.05)$ lower than during inspiration. All other pressure-frequenty combinations were cualitatively similar. BTPS Body temperature, ambiem messure and suturated with water lapour

pressure and frequency combinations investigated in this study.

\section{DISCUSSION}

We found that both normal subjects and CF patients had decreases in EELV during HFCC. At HP and at the higher oscillation frequencies, EELV decreased to less than $80 \%$ of the baseline FRC. We also found that transmission of HFCC induced pulse pressure across the chest wall to the pleural space was similar for normals and CF paltients. However, conversion of Pes-pp to Vose and to Vose was less efficiont in CF patients than in normal subjects, especially during spontaneous expiration.

Patients with airway obstruction tend to breathe al an elevated FRC, which minimizes the degree of airway closure (10) and it is generally considered undesirable for then 10 decrease EELV. Since HFCC decreases EELV one might expect widespread airwaly closure in CF patients who have significant airway obstruction. Although we did not observe a decrease in arterial oxygen saturation during short term HFCC, it should be recalled that $\mathrm{F}_{\mathrm{I}} \mathrm{O}_{2}$ was hept al approximately 0.5 during the studies. Typically, HFCC treatments are conducted over $3($ ) mins while the patients breathe room air so it is possible that hypoxemia could develop in that instance. On the other hand, $V_{T}$ increased during HFCC and it is possible that, at end-tidal inspiration, any airway closure is overcome and gas exchange may be reasonably well preserved. Also, HFCC, especially at the lower frequencies where Vosc is highest, may be beneficial to gas exchange 
( I I, 12). However, animal studies suggest that any bencficial effects of chest witl oscillation on gas exchange require larger, and not smaller. lung volumes (11). Studies during HFCC should be donc to determine whether the decreased EELV causes any significant effects on gals exchange.

We showed (lighre 4) that Vose, measured during sponlancous expiration, was considerably lower in CF patients than in nomal subjects and there was a kess well defined best frequency for Vose in the CF pationts. Wo believe this difference in Vosc between the two groups is related to the higher arway resistance in CF patients. Inereased airway resistance causes a latger time constant and. at a given Pespp, Vose will be lower. The decrease in EELV would be expected to catsos a lurther increase in time constant (1.3) and this maly contribute to the lower Vose that occurs with increasing HFCC frequency in both normals and CF pationts (Table 3).

Figure 5 shows that $\mathrm{Vosc}$ changes with FEV 1 and with the phase of spontaneous breathing. During inspiration Vosc was, without exception, higher than during expiration for both normals and CF paticnts. Also, the lower the FEV the greater was the disparty in Vose between inspiration and expiration. We believe this illustrates the influence of pleural pressure on airway resistince. The measurements in Figure 5 were obtained at the nidpoints of inspiration and expiration when lung volume and clastic pressure were similar. Therefore, differences in pleural pressure between midinspiration and midexpiation represent the pressure required lo overcomc resistance (14). For instance, at high background pressure and all $1.5 \mathrm{H} \%$, this resistive pressure. obtained from Pes-m, averaged 5.9 cm $\mathrm{H}_{2} \mathrm{O}$ in the mormal subjects and

ACKNOWLEDGEMENTS: This study was supported in part by a grant from American Biosystems Inc.

\section{REFERENCES}

I. King M, Phillips DM, Gross V. Vartian V, Chang HK, Zidulka A. Enhanced tracheal mucus ckarance with high frequency chest wall compression. An Rcv Respir Dis 1983;128:5 I I-5.

2. Gross D, Zidulka A, O'Brien C. ce il. Peripheral mucociliary clearance with high-frequency chesl wall compression. I Appl Physiol 1985;58: 1 157-63.

3. King M, Zidulka A, Phillips DM. Wight D, Gross D, Chimg HK. Tracheal mucus cleirance in high-frequency oscillation: cflect of peilk flow ralle hials. Eur Respir J 1990;3:6-13.

4. Beck (iJ. Chronic bronchial atshma and emphysema: rehabilitation and use of thoracic vibocompression. Geriatrics $1966: 21: 130-58$

5. Hansen LG. Warwich W.I. High-frequency chest compression system to aid in clearance of mucus from the lung. Biomed Instrum Technol I9(9);24:289-()4.

6. Warwick WJ, Hansion LG. The long-term effect of high-frequency chest compression therapy on pulmonary complications of cystic librosis. Pediatr Pulmoner 1991; I I:265-71.

7. Morris JF, Koski A. Johnson LC. Spironetric standards for healthy nonsmoking adults. Am Rev Rospir Itis 19) 71:103:57-67.

8. Crapo RO, Morris AH. (layton PD). Nixon (R. Lung volumes
$12.2 \mathrm{~cm} \mathrm{H}_{2} \mathrm{O}$ for the $\mathrm{CF}$ paticnts. The higher airway resistance, augmented by a more positive pleural pressure, causes Vose to be lower during expiration in CF pationts than in normals. This effect is greater when the degree of atrwaly obstruction is greater.

If HFCC-induced increases in mucus charance tepend on Vosic, then our results suggest that Cli patients with moderatc or severe airway obstruction may be less beneficially allfected by HFCC treatment than pationts with less atirwaty obstruction. However, this may be an oversimplistic vicw of the factors that affect mucus clearance. It is possible that the lower Vose in CF paltients with severe atrway obstruction. when accompanied by the decreased LEI, V that should lurther narrow the small airways (13), maly increatse alirfow velocity more than would be predicted from the low Vose. Recently, Arens et al (16) showed that daily HFCC therapeulic sessions given over a two-week period did improve lung function in CF patients with severe airwaty of struction.

Although we did not assess the effects of HFCC on mucus clearance, the highest Vosc occurred at cither 10 or $15 \mathrm{H}$ \% in the normal subjects and CF patients. This is similar to the frequency found most effective in enhancing mucus cicalance in nomal canine lungs ( 1 ).

In summary, we found that HFCC caused a decrease in EELV in hoth normal subjects and CF patients and that the magnitude of decrease in EELV was dependent on external chest wall pressure. The combination of inherently high airway resistance, decrease in EELV and positive pleural pressure during spontaneous expiration ciuses the ascillated flow rate to be low in CF patients, especially in those with mokerate or severe decreases in FEV 1 .

in healthy nomsinoking adults. Bull Eur Physiopathol Respor 1982;18:419-25.

9. Milic-Emili J, Mead J. Tumer JM. Gilauser EM. Inproved technique for estimating pleural pressure from esophageal balloons. J Appl Physiol 1964;19:207- II.

10. Leblanc P, Ruff F, Milic-Emili J. Effects of age and body position on "airway closure" in man. J Appl Physiol 1970;28:448-51.

I 1. Eyal FG, Hayek Z, Armengol J, Jones RL. Comparison ol high-frequency negative-pressure oscillation with conventional mechanical ventilation in normal and saline-lavaged cats. Cril Care Med 1986:14:724-9.

12. Zidulka A, Gross D, Minami H, Vartian V, Chang HK. Ventilation by high-frequency chest wall compression in dogs with normal lungs. Am Rev Respir Dis 1983;127:709-13.

13. Hughes JMB, Hoppin JR, Mead J. Effect of lung inflation on bronchial length and diameter in excised lungs. J Appl Physiol 1972:32:25-35.

14. Amdur MD, Mead J. Mechanics of respiration in unanesthetized guinea pigs. Am J Physiol 1958;192:364-8.

15. Hansen LG, Warwick WJ, Hansen KL. Mucus transport mechanisms in relation to the effect of high frequency chest compression (HFCC) on mucus clearance. Pediatr Pulmonol 1994; 17:1 13-8.

16. Arens R, Gozal D, Omlin KJ, et al. Comparative etticaky of ligh frequency chest compression and conventional chest physiotherapy in hospitalized patients will cystic fibrosis. Pediatr Pulmonol 1993;(Suppl 9):267. 


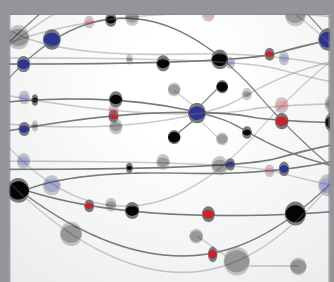

The Scientific World Journal
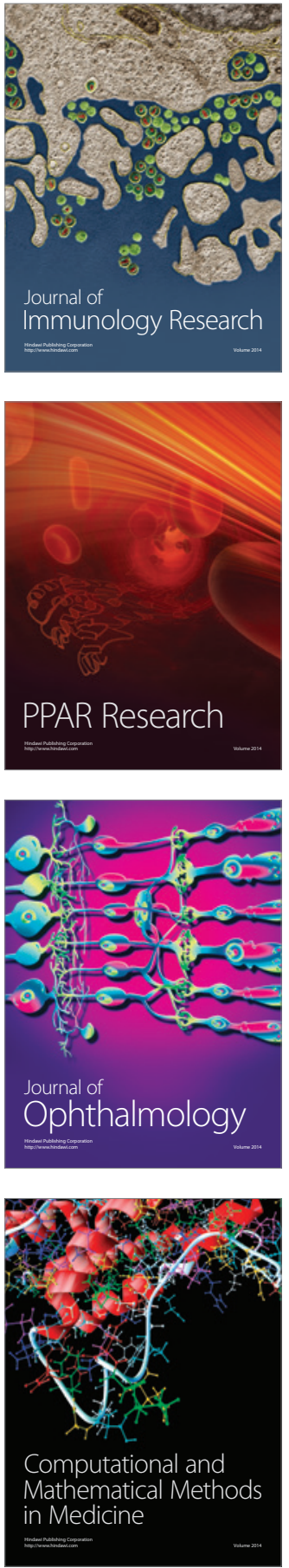

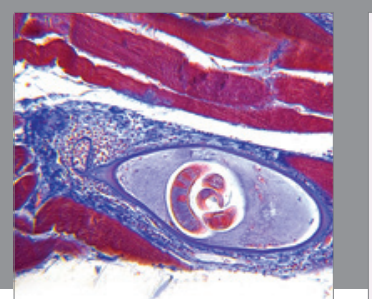

Gastroenterology Research and Practice

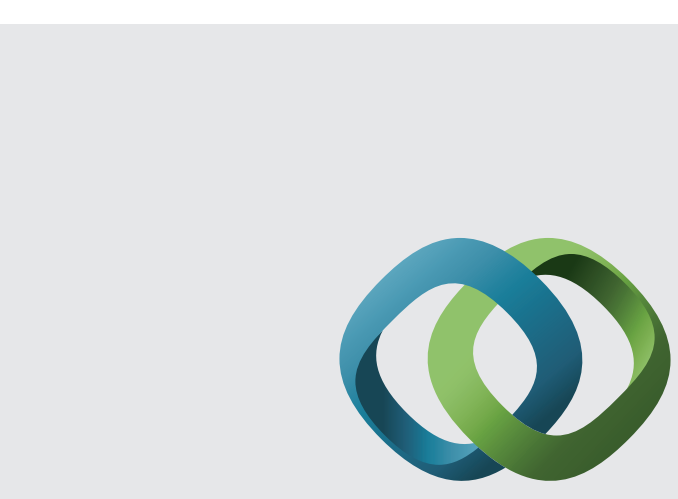

\section{Hindawi}

Submit your manuscripts at

http://www.hindawi.com
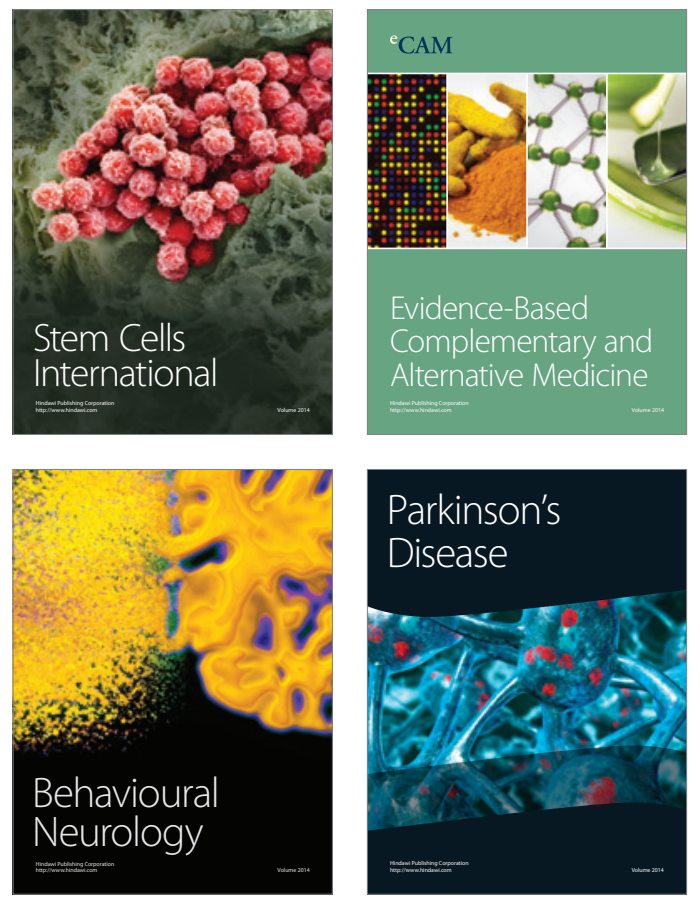
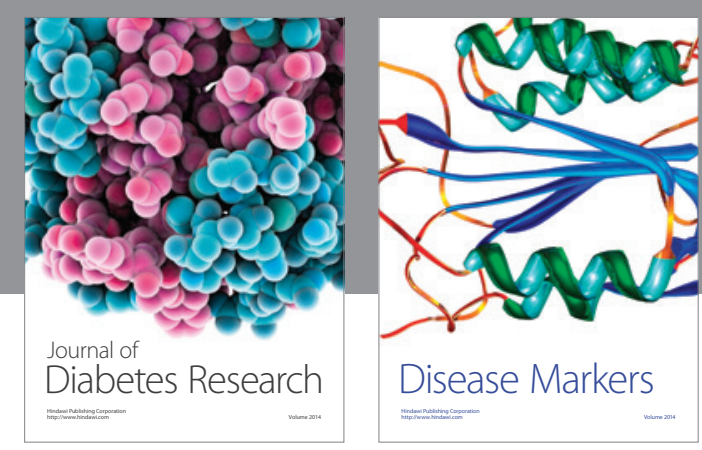

Disease Markers
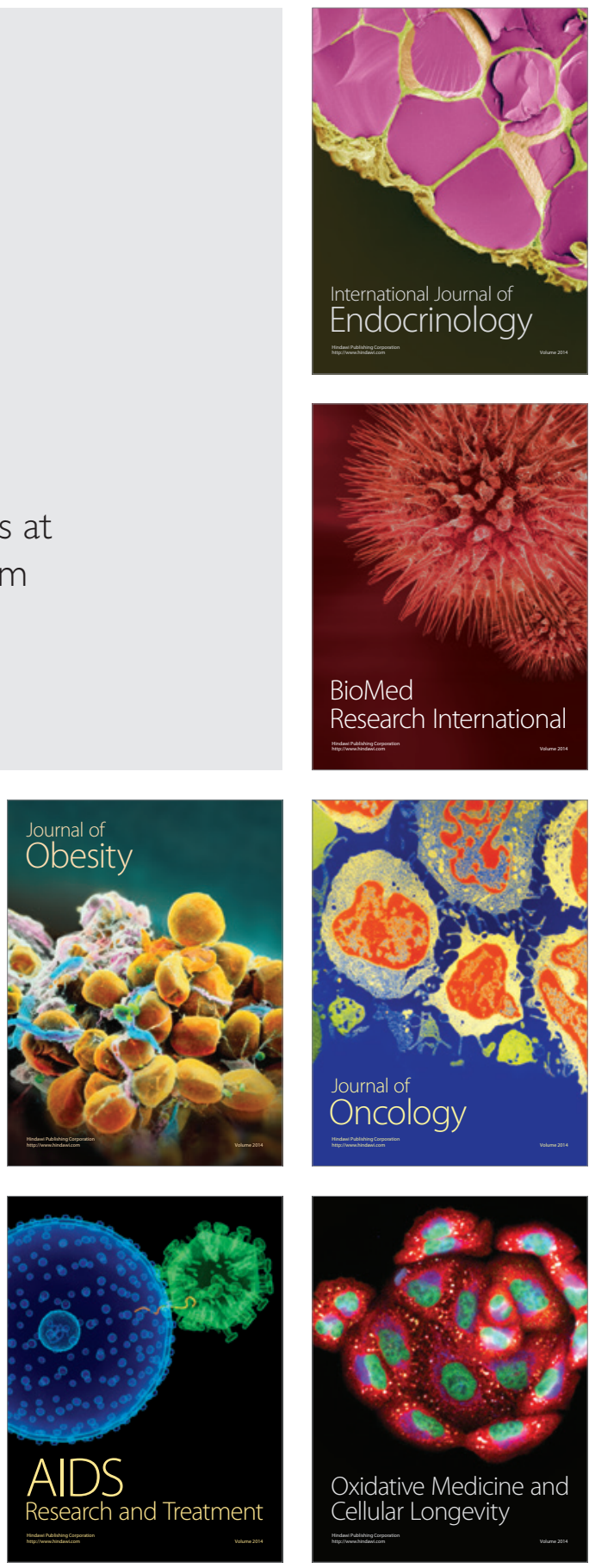